\title{
Intensive Growth Strategies and Outreach Performance of Tanzania-Based Savings and Credit Cooperative Societies
}

\author{
Kafigi Jeje ${ }^{1}$ \\ ${ }^{1}$ Department of Business Management, Institute of Accountancy Arusha, Tanzania \\ Correspondence: Kafigi Jeje, Assistant Lecturer, Department of Business Management, Institute of Accountancy \\ Arusha, Tanzania. E-mail: kjeje@iaa.ac.tz
}

Received: August 14, 2014

Accepted: November 12, 2014

Online Published: December 20, 2014

doi:10.5539/ijbm.v10n1p124

URL: http://dx.doi.org/10.5539/ijbm.v10n1p124

\begin{abstract}
Research on performance of Microfinance Institutions (MFIs) has attracted a great attention as the demand for microfinance services increases. One of the popular microfinance models is reaching the poor through Savings and Credit Cooperative Societies (SACCOs). A critical area is to assess what drives the SACCOs performance. Most research on SACCOs concentrate on assessing their performance without looking at the contribution of key performance drivers such as growth strategies. Little research has been done on the influence of intensive growth strategies (product development and market development) particularly on the SACCOs outreach performance in Tanzania. This study investigates the contribution of both product development and market development on outreach performance (increased number of SACCOs' members). Through a multiple regression analysis, the study tests seven hypotheses which are geared towards finding the contribution of both product development and market development on outreach performance. A cross-sectional survey design and multistage probability sampling technique enabled the participation of 167 key SACCOs' managers (loan officers) from three zones of Tanzania whose views were collected through questionnaires. The study has revealed the significant contribution of both product development and market development on outreach performance. SACCOs need to design growth strategies which suit the needs of their clients and their characteristics. Although an outreach performance can be driven by intensive growth strategies, we suggest that, the SACCOs' growth should also be harmonized with their financial performance.
\end{abstract}

Keywords: outreach performance, growth strategies, product development, market development, microfinance institutions, SACCOs, Tanzania

\section{Introduction}

For years, microfinance has been receiving a great deal of positive publicity (Lieberman, Anderson, Grafe, Campbell, \& Kopf, 2008). It has evolved as popular development aid tools and a major component of most financial systems in many less developed countries (Bogner \& Koivulehto, 2008; Gonzalez, 2007). Worldwide, Microfinance Institutions (MFIs) have grown at a burgeoning pace. There is a growth in outreach in terms of borrowers, Gross Loan Portfolio (GLP) and total assets (Commonwealth Secretariat, 2007). Microfinance is the type of financial services offered to poor and low income clients, where the unit size of the transaction is usually small. It operates in poor areas, offering financial services to low-income people through MFIs (Li, 2010). Its aim is to serve individuals who would face difficulties to access finance from banks, thought not to need financial services, considered un-creditworthy or too costly to serve. It can be offered, often without collateral, to an individual or through group lending (Hien, 2008).

MFIs are non-bank microfinance providers specializing in provision of microfinance services (Haq, 2008)to the low income people (Mori \& Munisi, 2009). In Tanzania, microfinance service providers include banks, non-governmental organizations (NGOs), SACCOs and a range of non-bank financial institutions (Rubambey, 2005). These institutions can also be grouped as NGOs; member-based microfinance institutions (MB-MFIs); and formal financial institutions (FFIs). The SACCOs fall under MB-MFIs (Nyamsogoro, 2010). SACCOs are institutions that play the role of a financial intermediary and are user-owned financial intermediaries (Zoom Microfinance, 2005; The Consultative Group to Assist the Poor [CGAP], 2005). SACCOs draw their membership from the local community or from a similar employer (Klinkhamer, 2009). Their members may share a geographic area, community, an employer, or other affiliation (CGAP, 2005). They can also target all 
community members in a given locality irrespective of their social and economic status (Shrestha, 2009). The members are the sole beneficiaries, sole savers and sole decision-makers (Mwakajumilo, 2011). The level of involvement of the members indicates the extent to which the institution is owned by the community (Duursma, 2004). In SACCOs, savings are linked to credit and they are both SACCOs' principal services. Their sources of fund come mainly from members' saving deposits (Shrestha, 2009). Mainly, these institutions offer savings and credits having members with equal voting rights, regardless of the number of shares they own. Cooperatives do provide affordable loans and insurance as well (Mwakajumilo, 2011; Almeyda \& Branch, 1998). They do sometimes join together for the purposes of building capacity, liquidity management, and refinancing (CGAP, 2005). This study concentrates on community-based SACCOs (those drawing members from communities irrespective of members' characteristics).

The demand for microfinance services has rarely been met by the formal financial sector (Delfiner \& Peron, 2007). From millions of micro entrepreneurs around the world, there is a large need for microfinance services (Lopez \& Rhyne, 2003; Lim, 2006). The global microfinance market is now offering a variety of services such as deposit accounts, housing finance, insurance, and money transfers (Sloand, 2010). Research indicates that MFIs need to go beyond offering traditional financial services such as credit (Campion, Ekka, \& Wenner, 2010). They need to modify existing products to better fit microenterprise clients (Westley, 2006). For instance, it is observed that customers consider service, speed and agility a much more important issue than the cost of a microloan (Delfiner \& Peron, 2007). In countries like India, Philippines, Sri Lanka, Thailand, and Vietnam, cooperatives constitute the major providers of microfinance service (Thapa, 2007). The microfinance sector in Tanzania is fast growing. There is a general increasing trends on both outreach and financial performance in the microfinance industry since 2002. Tanzanians provide potential growth opportunity for the MFIs (Nyamsogoro, 2010). Little research is done on the influence of intensive growth strategies (product development and market development) on outreach performance of Tanzania-based SACCOs. We therefore investigate whether there is a positive relationship between this growth and the growth strategies. The aim of this study is to find the contribution of intensive growth strategies on the outreach performance of SACCOs in Tanzania. Two intensive growth strategies adopted by SACCOs namely; product development and market development are linked with the outreach performance (increased number of SACCOs' members). Specifically it investigates the influence of:

1) product development on the outreach performance of SACCOs in Tanzania;

2) market development on the outreach performance of SACCOs in Tanzania.

This study is organised as follows; we first review various literatures on intensive growth strategies and MFIs' outreach performance. We also review theories explaining the use of intensive growth strategies and relate them with SACCOs' operations. We therefore find two theories; the Product Life Cycle and the Model of Competitive Advantage. These two theories are found to be useful in this study as they reveal the role of product development and market development to business performance. We therefore define SACCOs' product development, market development and outreach performance. Supported by literature, we formulate seven hypotheses which are tested using multiple regression analysis.

\section{Theoretical Development}

\subsection{The Product Life Cycle Theory}

Product Life Cycle Theory explains the introduction, growth, maturity, and decline stages of the products. The process of innovation and diffusion of a new product causes an industry growth to follow an S-shaped curve (Wit \& Meyer, 2004). It is a graph showing time against sales from introduction to decline (Wheelen \& Hunger, 2006). The service product lifecycle stages comprise of service innovation, service modification, differentiation of services and elimination of services (Bruhn \& Georgi, 2006). In the introduction phase, the firm's objective is to establish the brand in the market (Cravens, 2000) that is why this stage comprises of high production and marketing costs, and low profits (Peter \& Donnelly, 1998; Jobber, 1998). In the growth stage, there is an increased profit which has a positive relationship with sales (Peter \& Donnelly, 1998). Profit growth is fostered by swift market acceptance (Jobber, 1998) as many buyers rush into the market (Wit \& Meyer, 2004). In maturity stage and because of competition, profits for the initiating firm do not keep speed with sales as the product matures (Wit \& Meyer, 2004). The firm may be forced to initiate both product development and market development(Peter \& Donnelly, 1998; Jobber, 1998). During the decline phase, sales decline, and the firm decides whether to drop the product, change the product, change its use, develop markets or not(Peter \& Donnelly, 1998). In this stage, features of the product may also be modified (Cravens, 2000).

The SACCOs' products can also pass various stages of the PLC. For instance, in the introduction stage, heavy promotions and campaigns are required to raise awareness on the SACCOs, types of loans and their benefits, 
how to become a member, a borrower; and the importance of saving. These campaigns play a vital role in increasing the number of members, borrowers and savings. In the growth stage, the SACCOs' sales and profit increase. This is due to the fact that the savers, borrowers and the public in general have 'accepted' the services which were/are not fully provided by some commercial banks. The profit gained plays a vital role in sustaining the SACCOs' operations. At maturity stage, the SACCOs are not usually experiencing the rapid sales as witnessed during the growth stage. Reasons may be many including the competition. At this stage, the need to modify the services such as the existing loans is required. The SACCOs may also be required to reduce the interest rate and the time to process loans, promote its services and strive to recruit more members and borrowers At the decline phase, the level of savings from members, the trend of borrowing, profits and sales turn down. Here, the marketing expenditures in the campaigns to raise awareness on the SACCOs and their products and heavy costs during recruitment of more members and borrowers are cut down sharply. The SACCOs may decide to change the location of its business and find new members and borrowers, close its businesses or concentrate on few members and borrowers it has. However, strategies to modify the services provided by the SACCOs may be adopted to prevent the SACCOs from falling.

\subsection{The Model of Competitive Advantage}

When a firm applies strategies that cannot be duplicated or easily imitated by rivals, it is said to have a competitive advantage. This concept is achieved when there is value addition for customers (Papulova \& Papulova, 2006)or if a business system creates superior value for buyers (Wit \& Meyer, 2004). So, competitive advantage is achieved when a firm is able to increase economic value than its competitors (Rothaermel, 2008). Therefore, if a firm wants to achieve a position of competitive advantage, it must focus on cost and value. There is a relationship between competitive advantages and the resources firms hold and how they are managed. These resources must be managed to allow efficiency. The core of any competitive strategy is to derive customer satisfaction (Thompson \& Strickland, 2003) and the business will survive if the company gains an advantage (Papulova \& Papulova, 2006).

The model of competitive advantage helps SACCOs to plan for effective utilization of its resources. For instance, SACCOs can institute various low cost strategies in raising awareness to the public about their products, and recruit more members and borrowers. The low cost services offered by SACCOs can also enable them to price competitively. For instance, MFIs in Pakistan reported poor yield on GLP which was the result of poor pricing of their loans(Hussein \& Khan, 2009). On the other hand, a SACCO can use the competitive advantage model to offer its services differently from others and compete effectively. It may include the modifications on the existing loans such as time to process loans which is shorter than the time used by other SACCOs. These strategies can result into an increased number of savers, borrowers and members. The SACCOs can also concentrate on the segment which they can perform better. For instance, they may target farmers, micro and small businesspersons, and small scale miners and serve them better than serving the whole market which cannot easily be defined.

\subsection{Product Development}

The firm implements product development when it creates new products or improves the present products to suit the current markets. For services, it is a strategy that introduces new services for current market segments (Bruhn \& Georgi, 2006). We therefore define SACCOs' product development as frequent introduction of new types of loans, flexibility in changing the types of loans depending on the circumstance, frequent reduction of time to process and deliver the loan to the borrowers, and frequent changing of loan requirements.

\subsection{Market Development}

This refers to seeking new customers for current products. This strategy is used when current products are sold in new markets (Jobber, 1998). It is a strategy that utilizes present products. It may involve moving into new geographical markets or by moving into new market segments (Jobber, 1998).For services, a firm follows market development strategy if it focuses on new markets with the existing services. Here, the firm strives for customer acquisition by offering its new services to market segments which were not its previous customers (Bruhn \& Georgi, 2006). We define SACCOs' market development as a frequently raising awareness about the SACCOs and their products, frequently encouraging non members to join the SACCOs and frequently encouraging members to increase their savings. By encouraging members to increase their savings, it is assumed that, the SACCOs will increase their GLP which will eventually attract non members (prospective borrowers) to join the SACCOs.

\subsection{Outreach Performance}

Outreach is to extend microfinance services to the people who are underserved by financial institutions 
(Lafourcade, Isern, Mwangi, \& Brown, 2005). It refers to provision of financial access to a large number of borrowers who had previously been denied such service (Rahman \& Luo, 2010).It can be measured in terms of breadth; the number of clients both borrowers and savers (Barry \& Tacneng, 2009). The number of active clients includes borrowers, depositors, and others who are currently accessing any financial services (Rosenberg, 2009). Active clients are the ones having an outstanding loan balance with the MFI. They can also be the ones responsible for repaying any portion of the GLP (Frank, 2008). In this study, we define outreach performance as an increased number of SACCOs' members.

\subsection{Product Development and Outreach Performance}

Product development is needed to increase outreach (Lafourcade, Isern, Mwangi, \& Brown, 2005). Developing new products is valuable for SACCOs since it increases revenues. Product development creates additional value and reduces transaction costs associated with accessing financial services (Amha, 2008). According to Brand (1998), product development may include loan application time, criteria to access loan, and improvement on interest rate. There is an impact created by product development on SACCOs' performance. Due to this impact, additional products are offered. These products include emergency loans, insurance, and training (Brau \& Woller, 2004). Product development can reduce lending costs and increase the demand for loans (Amha, 2008). SACCOs can use this experience and that is why The International Bank for Reconstruction and Development [IBRD] (2004) proposes the need to think innovatively to increase rural outreach and to understand rural clients' needs, risks, and opportunities and develop specialized products. The role of product development can be seen in markets where varieties of services are preferred by poor people (Mulunga, 2010). These services include savings, insurance, and cash transfer depending on circumstances.

While some microfinance service providers are very innovative in introducing new products, others are satisfied with a single product. Those who focus only on loans are less efficient and are less productive than their counterparts. They are also less operationally self-sufficient and thus, can be deduced that they are less sustainable (Barry \& Tacneng, 2009). As the case in Asia and some parts of Africa, in Namibia for example, clients focus entails the provision of services that are needed by the microfinance clients (Mulunga, 2010). The same case is also happening in Ethiopia where the microfinance products lack diversification (Amha, 2000). They only depend on credit as their main financial product (Mulunga, 2010). The importance of product diversification is realized (Brau \& Woller, 2004) and it has led to higher number of borrowers and savers(Barry \& Tacneng, 2009). Modification of the products is needed to increase outreach. Failure to do so can lead to inefficiencies and poor productivity (Barry \& Tacneng, 2009). In this context, we therefore propose the following hypotheses;

i. There is a positive relationship between frequent introduction of new types of loans and an increased number of SACCO's members;

ii. There is a positive relationship between flexibility in changing the types of loans depending on the circumstance and an increased number of SACCO's members;

iii. There is a positive relationship between frequent reduction of time to process and deliver the loan to the borrowers and an increased number of SACCO's members;

iv. There is a positive relationship between frequent changing of loan requirements and an increased number of SACCO's members.

\subsection{Market Development and Outreach Performance}

For the MFIs to ensure accessibility to the poor, they need to be located within reach. The positive impact of market development will be realized if clients with economic business ideas to borrow for income generating projects are targeted (Mulunga, 2010). Market awareness must be balanced with its ability to meet client needs (Brand, 1998). Focus can be placed on a particular customer base, building strong relationships with customers and secure the larger market share (Brand, 1998) so that a new and loyal generation of clients can be realized as done by most Egyptian commercial banks (Segrado, 2005). The same strategy is adopted in Philippines where SACCOs are trusted by thousands of low-income people by receiving their deposits.

SACCOs must compete. They can compete well by developing the market through diversifying into niche market that banks cannot reach. They can also actively pursue niche markets and do much more proactive marketing of services (IBRD, 2004). However, upon doing market development, there are some challenges associated with serving the poor such as the increasing need for capital and the need for suitable infrastructure in very poor areas (Valdemar, Encinas, \& Imperio, 2007). The promotion of the MFI and its products to new or prospective members or users such as the campaign to raise awareness, to encourage them to become members, 
to persuade new members to save their money and take loans, can attract and increase more new users of microfinance products (Matul, Szubert, Cohen, \& McGuinness, 2006; Wright, Cracknell, Mutesasira, \& Hudson, 2003). In this context, we therefore propose the following hypotheses:

i. There is a positive relationship between frequently raising awareness about the SACCO and its products and an increased number of its members.

ii. There is a positive relationship between frequently encouraging non members to join the SACCO and an increased number of its members.

iii. There is a positive relationship between frequently encouraging members to increase their savings in the SACCO and an increased number of its members.

\section{Methodology}

\subsection{The Study Area}

This study was conducted in all the regions of Tanzania Mainland. The regions are classified into eight geographic zones: Western: (Tabora, Kigoma), Northern: (Kilimanjaro, Tanga, Arusha), Central: (Dodoma, Singida, Manyara), Southern Highlands: (Njombe, Iringa, Ruvuma), Lake: (Kagera, Mwanza, Mara, Shinyanga, Geita, Simiyu), Eastern: (Dar es Salaam, Pwani, Morogoro), Southern: (Lindi, Mtwara) and Southwest Highlands: (Rukwa, Katavi, Mbeya).

\subsection{Target Population}

All community-based SACCOs took part in this study. Accessing the latest total number of these SACCOs, age, size and their operations was challenging. However, a list of SACCOs that was used in the sampling procedure was established from different institutions in Tanzania such as the Ministry of Agriculture, Livestock and Cooperatives (Tanzania), Regional Offices (Tanzania) and The Savings and Credit Cooperative Union League of Tanzania (SCCULT).

\subsection{Sample Size}

To have a minimum variability, we assume that about 50 percent of these SACCOs operate so that to obtain the optimum number of SACCOs (n) sampled. This assumption gives the optimum sample size that could be taken. It is also assumed that the committed error is $7 \%$ and the significance level, $\alpha$ of $5 \%$. The conservative sample size is computed as follows:

$$
\mathrm{n}=\frac{Z^{2} \alpha / 2 \mathrm{pq}}{e^{2}}
$$

Where: $\alpha=0.5 \quad \mathrm{p}=0.5 \quad \mathrm{q}=1-\mathrm{p}=0.5 \quad \mathrm{e}=0.07 \quad \mathrm{Z}_{\alpha / 2}=1.96$

The optimum number of SACCOs selected for the sample is 196 .

\subsection{Sampling Procedure}

This study makes use of cross-sectional survey design. A multistage probability sampling technique is adopted. All the regions of Tanzania are stratified into eight (8) zones as shown above. Five zones are purposively selected followed by a random selection of three zones: Eastern, Northern and Central. Thereafter, systematic sampling is used to select the required number of SACCOs from each zone as shown in Table 1. Probability Proportional to Size (PPS) is therefore used to determine the number of SACCOs to be included in the sample from each zone.

Table 1. Number of SACCOs selected among the 8-zones

\begin{tabular}{lc}
\hline Zone & Number of SACCOs selected (Sample size) \\
\hline Eastern & 119 \\
Northern & 47 \\
Central & 30 \\
Total & 196 \\
\hline
\end{tabular}

\subsection{Data Collection and Analysis}

Data were collected through one hundred and ninety six (196) questionnaires with SACCOs' managers (loan officers) from three zones as shown in Table 1. Each manager represented his/her SACCO by filling one questionnaire. One hundred and sixty seven (167) questionnaires were returned and found useful for the purpose 
of the study. This represents $85.2 \%$ of the total questionnaires distributed (see Table 2). A multiple regression analysis is used to find the influence of intensive growth strategies (product development and market development) on the SACCOs outreach performance aided by a statistical tool PASW 16 (SPSS 16).

\section{Results}

It is observed that, members take loans to meet their agricultural, education, construction, business and other unforeseeable needs. On average, surveyed SACCOs set aside Tanzanian Shilling (TZS) 697.62 million annually for lending their borrowers. The average number of members in surveyed SACCOs is 554 per SACCO. The number of SACCOs that filled and returned the questionnaires is as follows;

Table 2. Number of questionnaires returned

\begin{tabular}{lcc}
\hline Zone & Questionnaires returned & Response rate (\%) \\
\hline Eastern Zone & 99 out of 119 & 83.1933 \\
Northern Zone & 42 out of 47 & 89.3617 \\
Central Zone & 26 out of 30 & 86.6667 \\
Total & 167 out of 196 & 85.2041 \\
\hline
\end{tabular}

\subsection{Hypothesis Testing}

4.1.1 The Influence of Product Development on Outreach Performance

In determining the influence of product development on the outreach performance of SACCOs in Tanzania, we have the following hypotheses;

$\mathrm{H}_{0}: \beta_{1}=0$

$\mathrm{H}_{1}: \beta_{1} \neq 0$

$\mathrm{H}_{0}: \beta_{2}=0$

$\mathrm{H}_{1}: \beta_{2} \neq 0$

$\mathrm{H}_{0}: \beta_{3}=0$

$\mathrm{H}_{1}: \beta_{3} \neq 0$

$\mathrm{H}_{0}: \beta_{4}=0$

$\mathrm{H}_{1}: \beta_{4} \neq 0$

Where $\beta_{0}, \beta_{1}, \beta_{2}, \beta_{3}$ and $\beta_{4}$ are coefficients for Constant, $X_{1}, X_{2}, X_{3}$ and $X_{4}$ respectively:

$\mathrm{X}_{1}$ denotes "frequent introduction of new types of loans".

$\mathrm{X}_{2}$ denotes "flexibility in changing the types of loans depending on the circumstance".

$\mathrm{X}_{3}$ denotes "frequent reduction of time to process and deliver the loan to the borrowers".

$\mathrm{X}_{4}$ denotes "frequent changing of loan requirements".

$\mathrm{Y}$ denotes "increased number of SACCO's members".

SACCOs' managers were asked to rate their level of agreement with $\mathrm{X}_{1}, \mathrm{X}_{2}, \mathrm{X}_{3}$ and $\mathrm{X}_{4}$ using a five-point scale (1. Strongly disagree, 2. Disagree, 3. Neither agree nor disagree, 4. Agree, 5. Strongly agree). The dependent variable $(\mathrm{Y})$ was determined based on number of members of the latest five consecutive years by 2012 in order to establish an increased number of members in the SACCO. We therefore put $Y$ in terms of percentage increase in SACCO's members. From these variables, a multiple regression equation is formulated as

$$
Y=\beta_{0}+\beta_{1} X_{1}+\beta_{2} X_{2}+\beta_{3} X_{3}+\beta_{4} X_{4}
$$


Table 3. Multiple regression output for a linear relationship between $\mathrm{Y}$ and $\mathrm{X}_{1}, \mathrm{X}_{2}, \mathrm{X}_{3}, \mathrm{X}_{4}$

Model Summary

\begin{tabular}{|c|c|c|c|c|c|c|c|}
\hline \multicolumn{2}{|c|}{ Model } & R Square & \multicolumn{2}{|c|}{ Adjusted R Square } & \multicolumn{3}{|c|}{ Std. Error of the Estimate } \\
\hline \multicolumn{2}{|c|}{1} & .354 & \multicolumn{2}{|c|}{.338} & \multicolumn{3}{|c|}{24.76243} \\
\hline \multicolumn{8}{|c|}{ a. Predictors: (Constant), $\mathrm{X}_{1}, \mathrm{X}_{2}, \mathrm{X}_{3}, \mathrm{X}_{4}$} \\
\hline \multicolumn{8}{|c|}{ ANOVA $^{\mathrm{b}}$} \\
\hline \multicolumn{2}{|r|}{ Model } & & Sum of Squares & $\mathrm{df}$ & Mean Square & $\mathrm{F}$ & Sig. \\
\hline \multirow[t]{3}{*}{1} & Regression & & 54393.421 & 4 & 13598.355 & 22.177 & $.000^{\mathrm{a}}$ \\
\hline & Residual & & 99334.854 & 162 & 613.178 & & \\
\hline & Total & & 153728.275 & 166 & & & \\
\hline
\end{tabular}

a. Predictors: (Constant), $\mathrm{X}_{1}, \mathrm{X}_{2}, \mathrm{X}_{3}, \mathrm{X}_{4}$;

b. Dependent Variable: Y.

Coefficients $^{\mathrm{a}}$

\begin{tabular}{|c|c|c|c|c|c|c|}
\hline & \multirow[b]{2}{*}{ Model } & \multicolumn{2}{|c|}{ Unstandardized Coefficients } & \multirow{2}{*}{$\begin{array}{c}\text { Standardized Coefficients } \\
\text { Beta } \\
\end{array}$} & \multirow[b]{2}{*}{$\mathrm{t}$} & \multirow[b]{2}{*}{ Sig. } \\
\hline & & B & Std. Error & & & \\
\hline \multirow[t]{5}{*}{1} & (Constant) & 125.549 & 59.901 & & 2.096 & .038 \\
\hline & $\mathrm{X}_{1}$ & -30.627 & 4.539 & -.491 & -6.747 & .000 \\
\hline & $\mathrm{X}_{2}$ & 13.623 & 3.416 & .269 & 3.989 & .000 \\
\hline & $\mathrm{X}_{3}$ & -12.429 & 5.348 & -.172 & -2.324 & .021 \\
\hline & $\mathrm{X}_{4}$ & 14.672 & 5.336 & .180 & 2.750 & .007 \\
\hline
\end{tabular}

a. Dependent Variable: Y.

As shown in Table $3, X_{1}, X_{2}, X_{3}$ and $X_{4}$ statistically significantly predict $Y, F(4,162)=22.177, p<0.05$. We can also see that $X_{1}, X_{2}, X_{3}$ and $X_{4}$ explain $35.4 \%$ of the variability of $Y$. We therefore set a new regression equation as;

$$
Y=125.549-30.627 X_{1}+13.623 X_{2}-12.429 X_{3}+14.672 X_{4}
$$

From the first hypothesis $\left(H_{0}: \beta_{1}=0, H_{1}: \beta_{1} \neq 0\right)$ we reject $H_{0}$ since $\beta_{1}(-30.627)$ is statistically significantly different from $0(p<0.05)$. Regarding the second hypothesis $\left(\mathrm{H}_{0}: \beta_{2}=0, \mathrm{H}_{1}: \beta_{2} \neq 0\right)$ we reject $\mathrm{H}_{0}$ since $\beta_{2}(13.623)$ is statistically significantly different from $0(\mathrm{p}<0.05)$. From the third hypothesis $\left(\mathrm{H}_{0}: \beta_{3}=0, \mathrm{H}_{1}\right.$ : $\left.\beta_{3} \neq 0\right)$ we also reject $\mathrm{H}_{0}$ since $\beta_{3}(-12.429)$ is statistically significantly different from $0(\mathrm{p}<0.05)$. Also, regarding the fourth hypothesis $\left(\mathrm{H}_{0}: \beta_{4}=0, \mathrm{H}_{1}: \beta_{4} \neq 0\right)$ we reject $\mathrm{H}_{0}$ since $\beta_{4}(14.672)$ is statistically significantly different from $0(\mathrm{p}<0.05)$.

4.1.2 The Influence of Market Development on Outreach Performance

In determining the influence of market development on the outreach performance of SACCOs in Tanzania, we have the following hypotheses;

$\mathrm{H}_{0}: \lambda_{1}=0$

$\mathrm{H}_{1}: \lambda_{1} \neq 0$

$\mathrm{H}_{0}: \lambda_{2}=0$

$\mathrm{H}_{1}: \lambda_{2} \neq 0$

$\mathrm{H}_{0}: \lambda_{3}=0$

$\mathrm{H}_{1}: \lambda_{3} \neq 0$

Where $\lambda_{0}, \lambda_{1}, \lambda_{2}$ and $\lambda_{3}$ are coefficients for Constant, $X_{11}, X_{12}$ and $X_{13}$ respectively:

$\mathrm{X}_{11}$ denotes "frequently raising awareness about the SACCO and its products".

$\mathrm{X}_{12}$ denotes "frequently encouraging non members to join the SACCO".

$\mathrm{X}_{13}$ denotes "frequently encouraging members to increase their savings". 
Y denotes "increased number of SACCO's members".

SACCOs' managers were asked to rate their level of agreement with $\mathrm{X}_{11}, \mathrm{X}_{12}$ and $\mathrm{X}_{13}$ using a five-point scale (1. Strongly disagree, 2. Disagree, 3. Neither agree nor disagree, 4. Agree, 5. Strongly agree). Again, the dependent variable (Y) was determined based on the number of members of the latest five consecutive years by 2012 in order to establish an increased number of members in the SACCO. We therefore put $\mathrm{Y}$ in terms of percentage increase in SACCO's members. From these variables, a multiple regression equation is formulated as

$$
Y=\lambda_{0}+\lambda_{1} X_{11}+\lambda_{2} X_{12}+\lambda_{3} X_{13}
$$

Table 4. Multiple regression output for a linear relationship between $\mathrm{Y}$ and $\mathrm{X}_{11}, \mathrm{X}_{12}, \mathrm{X}_{13}$

Model Summary

\begin{tabular}{ccccc}
\hline Model & $\mathrm{R}$ & $\mathrm{R}$ Square & Adjusted R Square & Std. Error of the Estimate \\
\hline 1 & $.590^{\mathrm{a}}$ & .348 & .336 & 24.79132 \\
\hline
\end{tabular}

a. Predictors: (Constant), $\mathrm{X}_{11}, \mathrm{X}_{12}, \mathrm{X}_{13}$.

\begin{tabular}{|c|c|c|c|c|c|c|}
\hline & Model & Sum of Squares & $\mathrm{df}$ & Mean Square & $\mathrm{F}$ & Sig. \\
\hline \multirow[t]{3}{*}{1} & Regression & 53546.899 & 3 & 17848.966 & 29.041 & $.000^{\mathrm{a}}$ \\
\hline & Residual & 100181.376 & 163 & 614.610 & & \\
\hline & Total & 153728.275 & 166 & & & \\
\hline
\end{tabular}

a. Predictors: (Constant), $\mathrm{X}_{11}, \mathrm{X}_{12}, \mathrm{X}_{13}$.

b. Dependent Variable: Y.

Coefficients $^{\mathrm{a}}$

\begin{tabular}{|c|c|c|c|c|c|c|}
\hline & \multirow[b]{2}{*}{ Model } & \multicolumn{2}{|c|}{ Unstandardized Coefficients } & \multirow{2}{*}{$\frac{\text { Standardized Coefficients }}{\text { Beta }}$} & \multirow[b]{2}{*}{$\mathrm{t}$} & \multirow[b]{2}{*}{ Sig. } \\
\hline & & B & Std. Error & & & \\
\hline \multirow[t]{4}{*}{1} & (Constant) & 190.840 & 22.042 & & 8.658 & .000 \\
\hline & $\mathrm{X}_{11}$ & 14.968 & 5.205 & .328 & 2.876 & .005 \\
\hline & $\mathrm{X}_{12}$ & -12.243 & 5.652 & -.248 & -2.166 & .032 \\
\hline & $\mathrm{X}_{13}$ & -31.647 & 3.968 & -.520 & -7.975 & .000 \\
\hline
\end{tabular}

a. Dependent Variable: Y.

As shown in Table $4, X_{11}, X_{12}$ and $X_{13}$ statistically significantly predict $Y, F(3,163)=29.041$, $p<0.05$. We can also reveal that $\mathrm{X}_{11}, \mathrm{X}_{12}$ and $\mathrm{X}_{13}$ explain $34.8 \%$ of the variability of $\mathrm{Y}$. We therefore derive the new regression equation as:

$$
Y=190.840+14.968 X_{11}-12.243 X_{12}-31.647 X_{13}
$$

From the first hypothesis $\left(\mathrm{H}_{0}: \lambda_{1}=0, \mathrm{H}_{1}: \lambda_{1} \neq 0\right)$ we reject $\mathrm{H}_{0}$ since $\lambda_{1}(14.968)$ is statistically significantly different from $0(\mathrm{p}<0.05)$. Regarding the second hypothesis $\left(\mathrm{H}_{0}: \lambda_{2}=0, \mathrm{H}_{1}: \lambda_{2} \neq 0\right)$ we reject $\mathrm{H}_{0}$ since $\lambda_{2}(-12.243)$ is statistically significantly different from $0(\mathrm{p}<0.05)$. Also, from the third hypothesis $\left(\mathrm{H}_{0}: \lambda_{3}=0\right.$, $\left.\mathrm{H}_{1}: \lambda_{3} \neq 0\right)$ we reject $\mathrm{H}_{0}$ since $\lambda_{3}(-31.647)$ is statistically significantly different from $0(\mathrm{p}<0.05)$.

\section{Discussion}

After testing the seven hypotheses of this study, it is revealed that, both product development and market development (intensive growth strategies) lead to outreach performance of SACCOs in Tanzania. These findings show that frequent introduction of new types of loans, flexibility in changing the types of loans depending on the circumstance, frequent reduction of time to process and deliver the loan to the borrowers and frequent changing of loan requirements influence the SACCOs outreach performance. The findings further reveal that frequently raising awareness about the SACCOs and their products, frequently encouraging non members to join the SACCOs and frequently encouraging members to increase their savings are key drivers of the outreach performance of Tanzania-based SACCOs. In Tanzania, SACCOs frequently introduce new types of loans to attract their borrowers. The types of loans are defined by their purposes or the role they play to improve lives of many SACCOs' borrowers. These purposes include agriculture, education, construction and business. SACCOs 
are also flexible in changing these purposes time after time by aiming at satisfying their borrowers. These strategies have led to increased number of members. When the number of members increases in these SACCOs, their performances increase too.

SACCOs are also modifying their loans to tap with the changes in the microfinance industry. These include the changing of loan requirements or criteria to access the loan as well as frequent reduction of time to process and deliver the loans to the members (prospective borrowers). When the SACCOs reduce 'barriers' to their members in accessing loans and soften the criteria, the possibility of increased number of loan applications becomes very high. However, SACCOs should also consider the expected profit before they introduce this strategy since softening the criteria may lead to increased number of loan defaulters and hence weaken their financial performance. Many users of SACCOs' services prefer less time in processing and receiving the loans. This is most of the time influenced by their needs' urgency. As already seen, the number of members increases as the modification continues. The modification of existing loans and the introduction of new loans to the members form an intensive growth strategy (product development) which plays a vital role in driving the outreach performance of SACCOs.

Again, the strategies used by the SACCOs in attracting people to the SACCOs and their services, in encouraging non members to save their money in SACCOsand take loans from the SACCOs are key drivers of their outreach performance in Tanzania. Many people would become members of the SACCOs should the campaign to raise awareness on the services particularly the loans be carried out. For instance, once the promotion on the importance of saving money in the SACCOs is well implemented, the possibility of an increased number of SACCOs' members becomes obvious and eventually the outreach performance increases. Also, once the campaign to attract new members and insist the old members to save money in their SACCOs is well implemented, the GLP of these SACCOs increases and eventually attracts the outsiders (non members) to join and hence an increased outreach performance. These strategies are part of an intensive growth strategy (market development) which when effectively implemented leads to an increased outreach performance of the SACCOs in Tanzania.

\section{Conclusion and Recommendations}

It has been revealed that SACCOs develop their products to attract their borrowers who use the money in running various projects in the areas of agriculture, education, construction and business in Tanzania. When product development is well implemented, it drives better outreach performance of SACCOs in Tanzania. Attracting more members and borrowers in the SACCOs is possible when SACCOs make developments on their services to meet the needs of their clients provided that the new developments do not affect their financial performance. Non members are also attracted by various marketing campaigns dedicated to raising awareness on the benefits of joining the SACCOs and their products.

SACCOs need to frequently carryout research in order to realize the needs of their clients. This will enable them to design effective strategies on how to increase their outreach performance. Through research, SACCOs will be able to understand the possible ways that suit the delivery of microfinance services to their members and eventually satisfy their needs. These researches should be undertaken successively so that they bring to light the current needs in such competitive markets. Carrying out studies regularly may become difficult to some SACCOs with weak financial muscles but it should be an inevitable exercise in the today's business environments where information has become one of the organization's assets.

SACCOs may concentrate on product development processes such as the reduction of time to process and deliver the loans to the borrowers and changing or 'softening' the criteria to access the loans aiming at increasing the outreach performance. However, SACCOs should take care of these strategies because the possibility of 'attracting' loan defaulters and increasing Non Performing Loans (NPL) may be higher due to 'loose' requirements/criteria. SACCOs may enjoy an increased number of members who borrow but unpleasant effects may be reflected on the financial performance such as poor yield on GLP especially when NPL increases. The modifications of the existing loans should not only focus on attracting non members but on the profit of the SACCOs as well. SACCOs should design their promotion strategies based on the nature of their services, prospective clients (the community), location, and communication channels. They should regularly perform these campaigns to remind the community about the products offered and their benefits to increase their client portfolios. SACCOs should carefully study and understand how best to manage and implement the required promotional mix in order to reach different remote clients.

\section{Acknowledgements}

I am grateful to Maagi Mapesi Thomas, Adonijah Abayo and Solomon E. Muguba for their helpful comments 
and suggestions.

\section{References}

Almeyda, G., \& Branch, B. A. (1998). Microfinance in Guatemala: The Case of Credit Unions. Madison, Wisconsin: World Council Information Center.

Amha, W. (2000). Review of Microfinance Industry in Ethiopia: Regulatory Framework and Performance. Addis Ababa: Association of Ethiopian Microfinance Institutions.

Amha, W. (2008). Innovations in the Delivery of Financial Services through the Deposit Taking Microfinance Institutions (MFIs) in Ethiopia. Retrieved May 23, 2011, from http://www.afraca.org/.../443Innovations\%20in\%20Building\%20financial\%20nclusiveness\%20

Barry, T. A., \& Tacneng, R. (2009). Governance, Performance and Diversification: Evidence From African Microfinance Institutions. $\quad$ Retrieved May 18, 2011, from http://southwesternfinance.org/conf-2010/F3-3.pdf

Bogner, S., \& Koivulehto, H. K. (2008). Should we Invest in Microcredit? A Financial Analysis of Microcredit from a USD-Investors Perspective. Working Paper as Part of the Dissertation of Hanna K.Koivulehto at the Vienna University of Economics and Business Administration, Vienna University of Economics and Business Administration, Vienna.

Brand, M. (1998). New Product Development for Microfinance: Evaluation and Preparation. Retrieved November 8, 2011, from http://pdf.usaid.gov/pdf_docs/PNACE722.pdf

Brau, J., \& Woller, G. M. (2004). Microfinance: A Comprehensive Review of the Existing Literature. Journal of Entrepreneurial Finance and Business Ventures, IX(1), 1-26.

Bruhn, M., \& Georgi, D. (2006). Services Marketing. Prentice Hall.

Campion, A., Ekka, R. K., \& Wenner, M. (2010). Interest Rates and Implications for Microfinance in Latin America and the Caribbean. Working Paper Series, Inter-American Development Bank.

CGAP. (2005). Working with Savings and Credit Cooperatives. Retrieved October 20, 2011, from http://cgap.org/gm/document-1.9.4396/DB25.pdf

Cochran, W. G. (1977). Sampling Techniques (3rd ed.). New York: John Wiley \& Sons.

Commonwealth, S. (2007). Microfinance and Innovative Financing for Gender Equality: Approaches, Challenges and Strategies. Retrieved October 13, 2011, from http://www.oecd.org/dataoecd/38/63/38831106.pdf

Cravens, D. W. (2000). Strategic Marketing (6th ed.). Irwin McGraw-Hill.

Delfiner, M., \& Peron, S. (2007). Commercial Banks and Microfinance. Retrieved May 26, 2011, from http://www.bcra.gov.ar/pdfs/invest/BcosComyMicrofi.pdf

DiLeo, P., \& FitzHerbert, D. (2007). The Investment Opportunity in Microfinance. Retrieved May 18, 2011, from http://www.iamfi.com/.../The\%20Investment\%200pportunity\%20in\%20Microfinance.pdf

Duursma, M. (2004). Community-Based Microfinance Models in East Africa. The Hague, Zeist and Dar es Salaam: Hivos, SNV-Tanzania and FACET BV.

Frank, C. (2008). Stemming the Tide of Mission Drift: Microfinance Transformations and the Double Bottom Line. Focus Note, Women's World Banking, New York.

Gonzalez, A. (2007). Resilience of Microfinance Institutions to National Macroeconomic Events:An Econometric Analysis of MFI asset quality. Munich Personal RePEc Archive (MPRA).

Haq, A. (2008). Microfinance Industry Assesment: A Report on Pakistan. Islamabad: Pakistan Microfinance Network (PMN).

Hien, V. M. (2008). Evaluate Performance Between Regulated and Non-regulated Microfinance Institutions in Southeast Asia Countries. National Cheng Kung University. Tainan: National Cheng Kung University.

Hussein, M. H., \& Khan, F. (2009). The State of Microfinance in Pakistan. Institute of Microfinance (InM).

IBRD. (2004). Microfinance and the Poor in Central Asia: Challenges and Opportunities. Agriculture and Rural Development Discussion Paper 6, Europe and Central Asia Region, World Bank, Agriculture and Rural Development Department, Washington, DC. 
Ireland, R. D., Hoskisson, R. E., \& Hitt, M. A. (2009). The Management of Strategy (8th ed.). South Western.

Isern, J., \& Porteous, D. (2005). Commercial Banks and Microfinance: Evolving Models of Success. Retrieved June $\quad 8, \quad 2011, \quad$ from http://ihfp.wharton.upenn.edu/.../CGAP\%20-\%20Commercial\%20Banks\%20and\%20Microfinance.pdf

Jobber, D. (1998). Principles and Practice of Marketing (2nd ed.). McGraw-Hill.

Klinkhamer, M. (2009). Microfinance Sector Recovery Study. Retrieved October 16, 2011, from http://www.snvworld.org/en/Documents/Microfinance\%20Sector\%20Recover\%20Study\%20\%20Zimbabw e.pdf

Lafourcade, A. L., Isern, J., Mwangi, P., \& Brown, M. (2005). Overview of the Outreach and Financial Performance of Microfinance Institutions in Africa. Retrieved May 25, 2011, from http://www.ruralfinancenetwork.org/pubs/MIX\%20Africa_Data_Study.pdf

Li, D. P. (2010). Measuring Social Performance of Microfinance Institutions in Peru. BA Thesis in Banking and Finance, University of Zurich, Swiss Banking Institute, Center for Microfinance Thesis Series, Zurich.

Lieberman, I. W., Anderson, A., Grafe, Z., Campbell, B., \& Kopf, D. (2008). Microfinance and Capital Markets: The Initial Listing/Public Offering of Four Leading Institutions. Retrieved May 20, 2011, from https://www.accion.org/Document.Doc?id=814

Lim, P. (2006). An Overview of the Micro Finance Industry: From its Early Days in the 1970's to 2005, the Year of Microcredit, and its Increasing Emphasis on Profit-Based Self-Sustaining Models. Retrieved May 19, 2011, from http://www.whymicrofinance.com/.../The_MicroFinance_Industry_Paper_Apr2006.pdf

Llanto, G. M. (2004). Is the Promise being Fulfilled?...Microfinance in the Philippines: Status, Issues and Challenges. Policy Notes, Philippine Institute for Development Studies, Makati City.

Lopez, C., \& Rhyne, E. (2003). The Service Company Model: A New Strategy for Commercial Banks in Microfinance. ACCION InSight No. 6, ACCION International, Boston.

Matul, M., Szubert, D., Cohen, M., \& McGuinness, E. (2006). Attracting the Unbanked: Preliminary Guidelines for Maximizing Existing Infrastructure Through Serving Untapped markets. Retrieved June 2, 2012, from $\mathrm{http} / / /$ microfinanceopportunities.org/docs/Attracting_the_Unbanked.pdf

Mokaddem, L. (2009). Concept Note on Microfinance Scaling up in Africa: Challenges Ahead and Way Forward. $\quad$ Retrieved May 27, 2011, from http://www.afdb.org/.../Concept\%20Note\%20Microfinance-\%20scaling\%20up\%20in\%20africa.pdf

Mori, N., \& Munisi, G. (2009). Strategic Decision Making in Microfinance Organizations: Stakeholder Perspective. First European Research Conference on Microfinance. Brussels.

Mulunga, A. M. (2010). Factors Affecting the Growth of Microfinance Institutions in Namibia. Master's Thesis, University of Stellenbosch, Stellenbosch.

Mwakajumilo, S. L. (2011). The Role of Informal Microfinance Institutions in Saving Mobilization, Investment and Poverty Reduction: A Case of Savings and Credit Cooperative Societies (SACCOS) in Tanzania From 1961-2008. PhD Thesis, St. Clement University, Turks and Caicos Islands.

Nieto, B. G., Cinca, C. S., \& Molinero, C. M. (2004). Microfinance Institutions and Efficiency. Universitat Politècnica de Catalunya.

Nirdhan Utthan Bank Ltd. (2010). Supply/Availability of Wholesale Funds for MFIs in Nepal: Challenges and Problems. A draft Paper Prepared for the Microfinance Summit Nepal on 14-16 February, 2010, Kathmandu, Nepal.

Nyamsogoro, G. (2010). Microfinance Institutions in Tanzania: A Review of Growth and Performance Trends. The Accountants, XXVI (3), 3-14.

Papulova, E., \& Papulova, Z. (2006). Competitive Strategy and Competitive Advantages of Small and Midsized Manufacturing Enterprises in Slovakia. Retrieved April 15, 2012, from http://www.g-casa.com/download/Papulova-CompetitiveStrategy.pdf

Peter, J. P., \& Donnelly, J. H. (1998). Marketing Management (5th ed.). Irwin/McGraw Hill.

Rahman, M. W., \& Luo, J. (2010). China: Comparing NGO-Type MFIs in Shaanxi, China, with Grameen Bank, Bangladesh. Banking With the Poor Network (BWTP): BWTP Bulletin-Providing an International Platform for Exploring Ideas and Findings on Microfinance in Asia. 
Rosenberg, R. (2009). Measuring Results of Microfinance Institutions: Minimum Indicators That Donors and Investors Should Track. Washington, DC: Consultative Group to Assist the Poor/The World Bank.

Rothaermel, F. T. (2008). Competitive Advantage in Technology Intensive Industries. In F. T. Rothaermel, Technological Innovation: Generating Economic Results Advances in the Study of Entrepreneurship, Innovation and Economic Growth (Vol. XVIII, pp. 201-225). Elsevier Ltd.

Rubambey, G. C. (2005). Policy, Regulatory and Supervisory Environment for Microfinance in Tanzania. Retrieved October 12, 2011, from http://www.microfinancegateway.org/gm/document-1.9.25859/29886_file_Tanzania_Essay_Ira.pdf

Segrado, C. (2005). The Involvement of Commercial Banks in Microfinance: The Egyptian Experience. MEDA Project, University of Torino, Torino.

Shrestha, S. M. (2009). State of Microfinance in Nepal. Retrieved November 4, 2011, from http://www.inm.org.bd/saarc/document/Nepal.pdf

Sloand, C. (2010). Supporting Growth and Stability of the Microfinance Industry in Sub-Saharan Africa: A Shifting Role for Development Agencies. Retrieved May 30, 2011, from

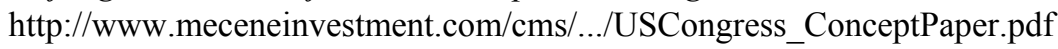

Stabell, C. B., \& Fjeldstad, Ø. D. (1998). Configuring Value for Competitive Advantage: On Chains, Shops, and $\begin{array}{lllll}\text { Networks. } & \text { Strategic Management } & \text { Journal, } & \text { XIX } & \text { (5), }\end{array}$ http://dx.doi.org/10.1002/(SICI)1097-0266(199805)19:5<413::AID-SMJ946>3.0.CO;2-C

Thapa, G. (2007). Sustainability and Governance of Microfinance Institutions: Recent Experiences and Some Lessons for Southeast Asia. Asian Journal of Agriculture and Development, 6(1), 18-36.

Thompson, A. A., \& Strickland, A. J. (2003). Strategic Management (13th ed.). McGraw-Hill.

Valdemar, D. C., Encinas, R. A., \& Imperio, A. M. (2007). Microfinance Activity in Philippines: Operational and Regulatory Challenges of the Microfinance Industry in Philippines. IDLO MF Working Paper, International Development Law Organization.

Wangwe, S. (2004). Innovation in Rural Finance in Tanzania. The Third Annual Conference on Microfinance. Arusha.

Westley, G. D. (2006). Strategies and Structures for Commercial Banks in Microfinance. Best Practices Series, Inter-American Development Bank, Sustainable Development Department, Micro, Small and Medium Enterprise Division, Washington, D. C.

Wheelen, T. L., \& Hunger, J. D. (2006). Strategic Management and Business Policy (10th ed.). Prentice Hall.

Wit, B. D., \& Meyer, R. (2004). Strategy:Process, Content, Context (3rd ed.). Thomson.

Wright, G. A., Cracknell, D., Mutesasira, L., \& Hudson, R. (2003). Strategic Marketing for MicroFinance Institutions. $\quad$ Retrieved June 2, 2012, from http://www.microfinancegateway.org/gm/document-1.9.28105/22629_ST_Strategic_Mkting.pdf

Zoom Microfinance. (2005). The Savings-Credit Cooperatives in Peru and Ecuador and the Development of Rural Financial Services. Brussels, Belgium and Grand Duchy of Luxembourg: SOS Faim-Action pour le développement.

\section{Copyrights}

Copyright for this article is retained by the author(s), with first publication rights granted to the journal.

This is an open-access article distributed under the terms and conditions of the Creative Commons Attribution license (http://creativecommons.org/licenses/by/3.0/). 